DOI 10. 18307/2018. 0512

(c) 2018 by Journal of Lake Sciences

\title{
鄱阳湖不同湖区营养盐状态及藻类种群对比
}

\author{
彭宁彦 ${ }^{1,2}$, 戴国飞 ${ }^{2 * *}$, 张 伟 ${ }^{2}$, 葛 刚 $^{1 * *}$, 杨 平 $^{2}$, 郭春晶 ${ }^{2}$, 方媛瑗 ${ }^{2}$ \\ (1: 南昌大学生命科学学院,南昌 330031$)$ \\ $(2$ : 江西省水利科学研究院, 南昌 330029$)$
}

\begin{abstract}
摘 要: 在平水期、丰水期和枯水期对鄱阳湖典型天然碟形湖、人控湖汉和主湖区进行了水质、藻类和蓝藻毒素等对比调 查, 结果表明鄱阳湖各个湖区的水质与藻类种群等差异较大, 蓝藻毒素浓度和底泥中铁含量的分布具有一定关联性. 在 各水文季节蓝藻均为人控湖汉藻类的主要优势种之一. 平水期鄱阳湖藻类生物量 (叶绿素 $\mathrm{a}$ 浓度) 与水体的 $\mathrm{pH}$ 呈正相关 关系, 与采样点的水深呈负相关关系, 碟形湖区水体营养盐浓度和藻类细胞密度均较其他湖区水体低. 丰水期各湖区的 水质差异相对较小, 碟形湖藻类细胞密度仍低于其他湖区, 但蓝藻已成为各湖区的优势种, 该时期藻类生物量与水体总 磷浓度及浊度呈正相关关系. 枯水季鄱阳湖各水体藻类生物量与水体总氮浓度、铵态氮浓度及电导率呈正相关关系, 碟 形湖与主湖区发生了完全分离, 水体流动性差, 暴发蓝藻水华的风险较高. 高温丰枯季节鄱阳湖水体蓝藻毒素浓度与底 泥铁含量呈现一定的相关分布关系, 底泥铁含量高的地方, 其水体蓝藻毒素浓度通常比较高, 应警惕鄱阳湖流域富铁红 壤流失带来的湖区蓝藻水华风险加剧后果. 上述研究结果将为鄱阳湖水环境的预警和污染控制提供科学指导.
\end{abstract}

关键词: 蓝藻水华;微囊藻毒素;鄱阳湖;碟形湖;水生态安全

\section{Differences in nutrition condition and algae population in different areas of Poyang Lake}

\author{
PENG Ningyan ${ }^{1,2}$, DAI Guofei ${ }^{2 * *}$, ZHANG $\mathrm{Wei}^{2}$, GE Gang ${ }^{1 * *}$, YANG Ping $^{2}$, GUO Chunjing ${ }^{2}$ \& \\ FANG Yuanyuan ${ }^{2}$ \\ (1: School of Life Sciences, Nanchang University, Nanchang 330031, P.R.China) \\ (2: Jiangxi Institute of Water Sciences, Nanchang 330029, P.R.China)
}

\begin{abstract}
Shallow dished lakes, isolated bays and the main water body of Poyang Lake were studied during common water period, flood period and drought period. The water, phytoplankton and dissolved microcystin samples were collected and analyzed. Results showed that in all periods, water quality and algae population varied greatly among the three areas. Dissolved microcystin concentration correlated well with Fe content in the sediment. Cyanobacteria was the dominant specie in the isolated bays during all periods. In common water period, algae biomass was positively correlated with $\mathrm{pH}$ and negatively correlated with water depth. Nutrient concentrations and algae cell density in the shallow dished lakes were much lower than those of the other water bodies. In flood period, algae biomass was positively correlated with total phosphorus concentration and turbidity while variance of water quality among different water bodies was relatively small. Cyanobacteria, especially Microcystis, became the dominant specie in all water bodies, while algae cell density and biomass in the shallow dished lakes were the lowest. In drought period, shallow dished lakes were isolated from the main water body of Poyang Lake with very poor water mobility, which may increase the risk of algae bloom. Algae biomass was positively correlated with total nitrogen, ammonia nitrogen and water conductivity. In both flood and drought periods with high temperature condition, dissolved microcystin concentration correlated well with Fe content in the sediment. This indicated that Fe may promote microcystin production and Fe enriched red soil erosion around Poyang Lake may exacerbate the risk of algae bloom. The present study can provide some guidance for water pollution control and aquatic environment risk warning of Poyang Lake.
\end{abstract}

* 国家自然科学基金项目(31660138, 31400405)、水利部科技推广项目( TG1520) 和江西水利科技项目( TG201501, KT201602) 联合资助. 2017-12-15 收稿; 2018-01-18 收修改稿. 彭宁彦 (1987 ), 女, 硕士研究生; E-mail: cherrierain@vip.qq.com.

** 通信作者;E-mail:daiguofei@ whu.edu.cn; gge@ ncu.edu.cn. 
Keywords: Cyanobacteria bloom; microcystin; Poyang Lake; shallow dished lakes; aquatic ecosystem security

鄱阳湖为我国目前最大的淡水湖, 是一个过水性、吞吐型、季节性的湖泊. 其丰水期与枯水期的面积和 容量相差悬殊,造就“丰水一大片, 枯水一条线”的奇特景观. 当前, 随着鄱阳湖流域人口的增长、工业化和城 市化进程的加快, 特别是近年来鄱阳湖流域水产养殖业、矿产业、采沙业及沿湖工业和城镇化的不断发展, 其湖区生态环境形势总体日益严峻, 目前局部范围内已发生轻度富营养化甚至新型复合环境污染问题 ${ }^{\left[{ }^{1]}\right.}$. 近几年存在尤为突出的人为活动如围网、围堤、底栖螺类大规模机械化产业化捕捞等活动,使局部区域生境 破碎和生物栖息地减少, 湖泊生态系统失衡, 湖区出现蓝藻水华. 湖泊生态功能退化和富营养化藻类水华的 发生将严重影响当地百姓的生产、生活甚至饮用水安全, 湖泊生态安全问题已成为制约区域社会经济可持 续发展的重要因素之一 ${ }^{[2-3]}$.

鄱阳湖五大支流赣江、抗河、修河、饶河与信江进入湖区时, 人湖河口三角洲受水流冲刷不断发育. 由于 水流与泥沙沉积作用, 在河口三角洲形成许多浅碟形洼地, 其内部充水时即形成碟形湖. 丰水期碟形湖与主 湖区连为一体, 枯水期当星子水位低于黄海高程 $13 \mathrm{~m}$ 时, 所有碟形湖均与主湖区脱离水流联系自然分离成 相对独立水体, 其水位与主湖区没有关联, 仅受到蒸发、降水和人为放水影响. 鄱阳湖湖盆中面积超过 $2 \mathrm{~km}^{2}$ 的碟形湖共有 75 个,枯水期其水面面积与鄱阳湖主湖区水面面积相当. 碟形湖具有特殊的水文过程, 即使 枯水期主湖区水位较低, 碟形湖仍可以保持较高水位, 水深 $0.5 \sim 1 \mathrm{~m}$ 左右. 碟形湖中浮游生物、底栖动物和 鱼类丰富, 周边萄草群丛占优势, 生物多样性丰富, 为越冬候鸟提供了丰富的食物来源和良好的夜宿和隐蔽 环境 ${ }^{[4]}$. 近年来鄱阳湖碟形湖区同样存在过度人为开发倾向, 2012 年 10 月鄱阳湖南矶湿地国家自然保护区 中部分碟形湖, 如战备湖及周边航道区域, 由于鱼类饤料过量投加暴发了较重的蓝藻水华, 引起了众多社会 媒体和科研机构的广泛关注 ${ }^{[5]}$. 相比不同水文季节碟形湖与主湖区时而连通、时而分离的状态, 鄱阳湖区的 人控湖汉则与主湖区发生了完全分离, 仅在汛涝干旱等极端情况需排水补水时才发生临时性水体交换, 其 水质与藻华风险情况较少受到关注.

剧烈变动的水文水动力条件是鄱阳湖最为突出的自然因素之一, 研究表明水动力对湖泊生物群落演替 起重要作用, 藻类种类数以小水流时最高, 其生物量也最高. 湖泊水库丰水期由于水体滞留时间变长和流速 变缓, 藻类拥有更长时间的生长繁殖, 在适宜的营养条件下数量往往会显著增长 ${ }^{[6-7]}$. 通常水位水量的提高 也会伴随着水体营养盐被稀释及水体中下层光照的减弱屏蔽, 同样也可能抑制藻类的生长. 垂直混合是蓝 藻表层水华能否形成的重要因子, 蓝藻进行光合作用, 其生长必须保持在透光层 ${ }^{[8]}$. 大部分浮游植物在水体 中被动运动, 因此带有伪空泡结构的漂浮性蓝藻在弱混合的水体中具有竞争优势, 该现象在深水水体中尤 为明显. 在许多水生态系统中, 水体剧烈扰动时硅藻或绿藻占优势, 而当水体扰动较弱时则优势种转变为蓝 藻 ${ }^{[9-10]}$. 人为干扰如水产养殖和工业生活废水的排放可使水体中的营养盐在短时间内快速提高, 特别是氮、 磷类营养物质. 研究发现, 通常藻类增长受到磷限制甚于氮限制, 磷为制约湖泊藻类生长的营养元素, 水体 中磷负荷大量增加时, 藻类便会迅速大量繁殖, 一般认为低氮磷比有利于蓝藻在水体中形成优势 ${ }^{[11]}$. 生物因 素也是影响藻类水华的一个重要因子, 水生植物在改善湖泊环境, 减轻富营养化水平和控制水华形成方面 有重要作用, 如灰化苔草可抑制微囊藻的生长 ${ }^{[12]}$.

鉴于鄱阳湖自身及其湖盘中数量与面积巨大的碟形湖具备的显著地域特点和个案特征, 本研究将选取 不同水文季节里的鄱阳湖主湖区、低人为干扰的天然碟形湖区和高人为干扰的人控湖汉作为研究对象, 比 较鄱阳湖各子水域水体在不同水文季节的营养盐特征及其藻类数量和种群结构的差异, 分析各水域蓝藻水 华风险成因, 从而更加全面深刻地认识鄱阳湖不同水域富营养化现状和藻类演变的规律, 以期为鄱阳湖水 环境的预警和污染控制提供科学指导.

\section{1 样品与方法}

\section{1 样点选择与样品采集}

于 2014-2015 年选择典型的平水期 (4、5 月各一次采样)、丰水期 ( 7、8 月各一次采样) 和枯水期 (10 月 底至 11 月初一次采样) 对 9 个天然碟形湖 (分别为大汉湖、大湖池、北甲湖、下深湖、战备湖、常湖、上深湖、 
泥湖和赣江一大汉湖过渡水域)、4 个人控湖叉 (分别为军山湖、新妙湖 (都昌县)、南北湖 (湖口县) 和陈家 湖) 和鄱阳湖主湖区 10 个点位进行水质和浮游植物等调查采样 (图 1). 水样采集后分装于聚乙烯瓶中, 部 分水样加 $\mathrm{H}_{2} \mathrm{SO}_{4}$ 酸化保存, 除温度、 $\mathrm{pH}$ 及透明度现场测定外, 其他水质参数均于采样后 $8 \mathrm{~h}$ 内测定. 藻类定 性样品采集使用 $25^{\#}$ 浮游植物网浓缩, 藻类定量样品采 $1 \mathrm{~L}$ 水样加人鲁哥试剂固定后沉淀 $24 \mathrm{~h}$, 然后将底部 沉淀物 (约 $30 \mathrm{ml}$ ) 转人 $50 \mathrm{ml}$ 定量瓶中, 经过超声波处理后通过血球计数板计数. 微囊藻毒素样品在水样采 集后,立即用 $0.45 \mu \mathrm{m}$ 滤膜过滤去除水中杂质, 然后装人棕色小玻璃瓶中迅速放人便携式冰箱中保存待测.

\section{2 样品分析与评价}

常规水质指标包括总磷 $(\mathrm{TP})$ 、总氮 $(\mathrm{TN})$ 、铵态氮 $\left(\mathrm{NH}_{4}^{+}-\mathrm{N}\right)$ 、透明度 $(\mathrm{SD})$ 、高锰酸盐指数 $\left(\mathrm{COD}_{\mathrm{Mn}}\right)$ 、溶解 氧 (DO) 和叶绿素 a (Chl.a) 等均采用国标法测定, 水体电导率和浊度使用便携式水质监测仪 YSI-EXO(YSI 公司, 美国) 现场测定, 底泥重金属比如底泥铁含量的测定采用的是电感耦合等离子体质谱法 ${ }^{[13]}$. 水体中的 蓝藻毒素测定使用间接竞争 ELISA ( enzyme-linked immunosorbent assay) 法, 其简略流程如下: ELISA 板包被 完毕后, 在样品浓度测试时把样品和毒素标准梯度溶液 $(0 、 0.1 、 0.5 、 1 、 2$ 和 $4 \mathrm{ng} / \mathrm{ml})$ 加人 96 孔板, 然后加人 单抗溶液反应 60 90 min, 用 PBS-T 洗板 3 次. 加人稀释后的二抗溶液反应 $0.5 \mathrm{~h}$, 洗板 5 次, 最后加人 TMB 显色液显色 $15 \mathrm{~min}$ 左右, 观察溶液颜色变化, 加人 $1 \mathrm{~mol} / \mathrm{L}$ 的硫酸终止反应, 在 $450 \mathrm{~nm}$ 波长下测定吸光度 值, 根据吸光度值, 计算样品中毒素的浓度 ${ }^{[14]}$.

本文采用综合营养状态指数 $(T L I)$ 水体富营养化评价法对鄱阳湖不同水域进行富营养化分析. $T L I$ 评价 法是中国环境监测总站推荐的湖泊水库富营养化评价方法, 其综合考虑了包括叶绿素 $\mathrm{a} 、$ 总磷、总氮、透明度 和高锰酸盐指数等参数, 并主要以上述 5 项水质指标检测值进行计算, 目前已被大量应用于我国湖泊水库 的富营养化评价研究中 ${ }^{[15-16]}$. 浮游植物计数鉴定采用血球计数板法, 主要参考文献 [17-18]. 优势种采用 Mcnaughton 指数 $Y$ 确定: $Y=\left(n_{i} / N\right) f_{i}$, 式中, $n_{i}$ 为第 $i$ 种藻类的细胞数, $N$ 为样品中所有藻类的总细胞数, $f_{i}$ 为第 $i$ 种藻类在各样点出现的频率, 取优势度指数 $Y>0.02$ 的藻类定为优势种 ${ }^{[19]}$.

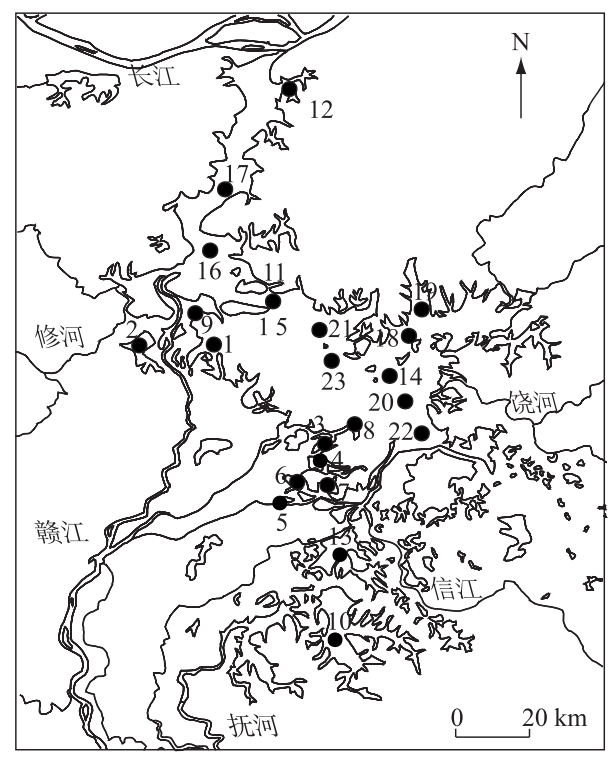

图 1 鄱阳湖各湖区采样点分布

Fig.1 Distribution of sampling sites in Poyang Lake

\section{2 结果}

\section{1 平水期鄱阳湖各水域水体营养盐及藻类状况}

平水期鄱阳湖水位较低,碟形湖与主湖区多处于半分离状态 (通过小型渠流发生水体交换). 平水期鄱 
阳湖碟形湖区总磷浓度范围为 $0.016 \sim 0.069 \mathrm{mg} / \mathrm{L}$, 平均值为 $0.032 \mathrm{mg} / \mathrm{L}$; 主湖区总磷浓度范围为 $0.041 \sim$ $0.082 \mathrm{mg} / \mathrm{L}$, 平均值为 $0.061 \mathrm{mg} / \mathrm{L}$; 人控湖汉总磷浓度范围为 $0.090 \sim 0.162 \mathrm{mg} / \mathrm{L}$, 平均值为 $0.124 \mathrm{mg} / \mathrm{L}$ (图 $2 \mathrm{a})$. 总磷浓度在天然碟形湖一主湖区一人控湖汉间接近以翻倍的形式上升, 表明该时期人控湖汉和主湖区 受外来干扰较多. 平水期天然碟形湖总氮浓度范围为 $0.082 \sim 1.083 \mathrm{mg} / \mathrm{L}$, 平均值为 $0.573 \mathrm{mg} / \mathrm{L}$; 主湖区总氮 浓度范围为 $0.778 \sim 1.771 \mathrm{mg} / \mathrm{L}$, 平均值为 $1.399 \mathrm{mg} / \mathrm{L}$; 人控湖汉总氮浓度范围为 $0.764 \sim 1.051 \mathrm{mg} / \mathrm{L}$, 平均值 为 $0.889 \mathrm{mg} / \mathrm{L}$, 相比于其他湖区, 天然碟形湖总氮浓度总体依然较低 (图 $2 \mathrm{~b}$ ). 综合富营养化指数方面, 天然 碟形湖变化范围为 26.7 50.4, 平均值为 37.5, 总体处于中营养状态; 主湖区综合富营养化指数变化范围为 $45.9 \sim 57.6$, 平均值为 51.3 , 总体处于轻度富营养化状态; 人控湖汊变化范围为 $47.2 \sim 57.3$, 平均值为 51.0 , 总 体处于轻度富营养化状态 ( 图 2c).
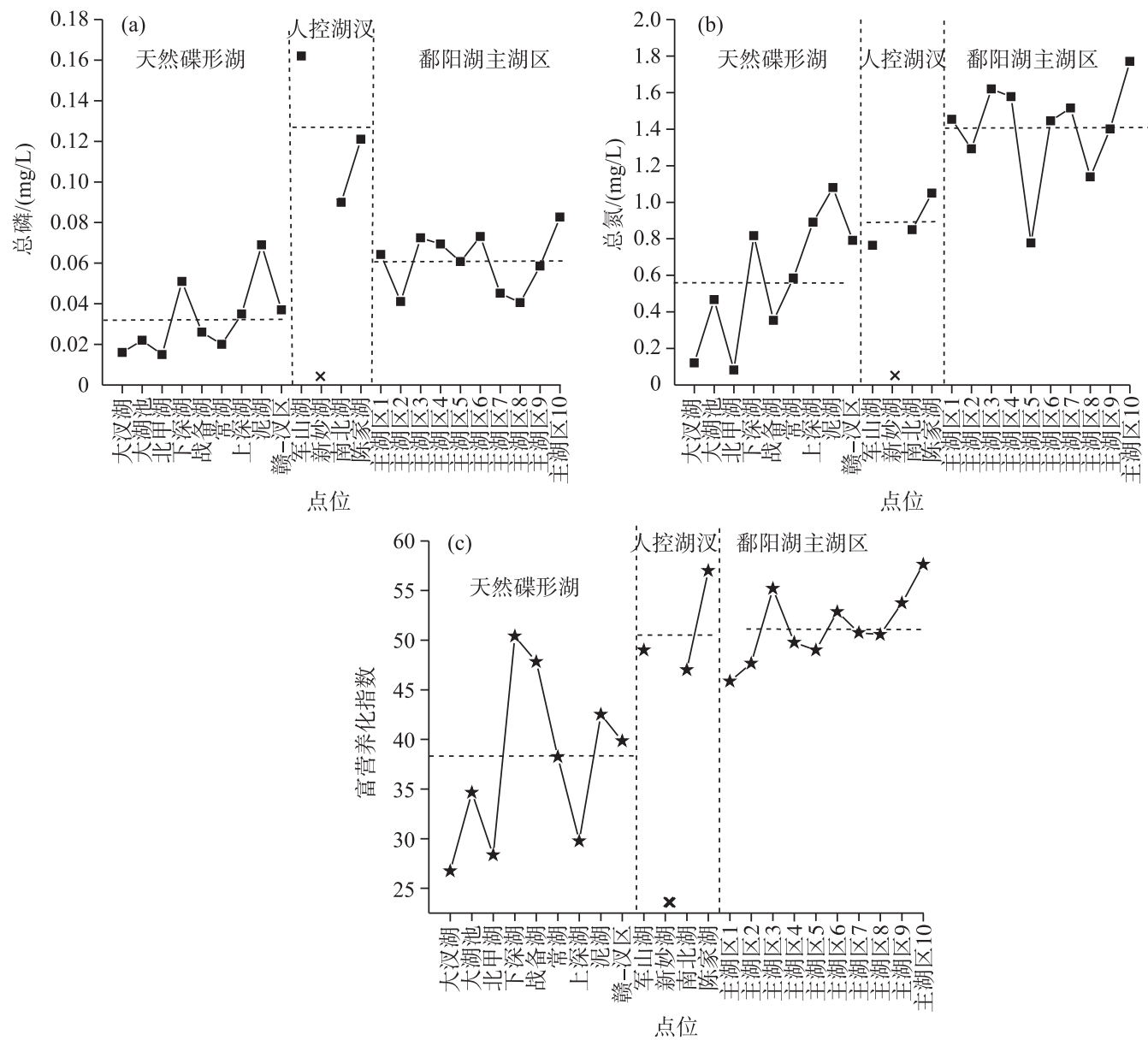

图 2 平水期鄱阳湖各湖区总磷 ( a )、总氮 (b) 和富营养化指数 (c) (水平虚线代表平均值)

Fig.2 Concentrations of total phosphorus (a), total nitrogen (b) and comprehensive nutrition state index (c) in different areas of Poyang Lake during common water period

鄱阳湖碟形湖平水期藻类细胞密度变化范围为 $4.841 \times 10^{5} \sim 3.889 \times 10^{6} \mathrm{cells} / \mathrm{L}$, 平均值为 $1.951 \times 10^{6}$ cells/L, 藻细胞生物量变化范围为 $0.364 \sim 2.745 \mathrm{mg} / \mathrm{L}$, 平均值为 $1.193 \mathrm{mg} / \mathrm{L}$, 绿藻、硅藻和隐藻在数量和生物量 上均占优势地位; 主湖区藻细胞密度变化范围为 $3.865 \times 10^{6} \sim 2.490 \times 10^{7}$ cells $/ \mathrm{L}$, 平均值为 $8.586 \times 10^{6}$ cells $/ \mathrm{L}$, 生 物量变化范围为 $6.604 \sim 11.185 \mathrm{mg} / \mathrm{L}$, 平均值为 $8.493 \mathrm{mg} / \mathrm{L}$, 绿藻、硅藻和蓝藻在数量上占据优势地位, 硅 藻、绿藻和隐藻等在生物量上为优势种; 人控湖汊藻细胞密度变化范围为 $4.802 \times 10^{6} \sim 7.303 \times 10^{6}$ cells $/ \mathrm{L}$, 平 
均值为 $5.695 \times 10^{6}$ cells $/ \mathrm{L}$, 生物量变化范围为 $0.884 \sim 2.571 \mathrm{mg} / \mathrm{L}$, 平均值为 $1.588 \mathrm{mg} / \mathrm{L}$, 蓝藻在数量上为主 要优势种, 硅藻、蓝藻和绿藻等在生物量上为优势种 (图 3). 对平水期藻类 (叶绿素 a) 及多水质参数进行 Pearson 相关分析, 结果表明, 水体叶绿素 a 浓度与 $\mathrm{pH}$ 呈正相关关系, 与采样点的水深呈负相关关系, 总氮 与总磷间也具有较好的正相关性 (表 1). 平水期在鄱阳湖各水域抽取的点位中, 水体微囊藻毒素浓度均在 ELISA 法的检测限 $(0.1 \mu \mathrm{g} / \mathrm{L})$ 以下,表明该季节鄱阳湖中产毒蓝藻量较少.

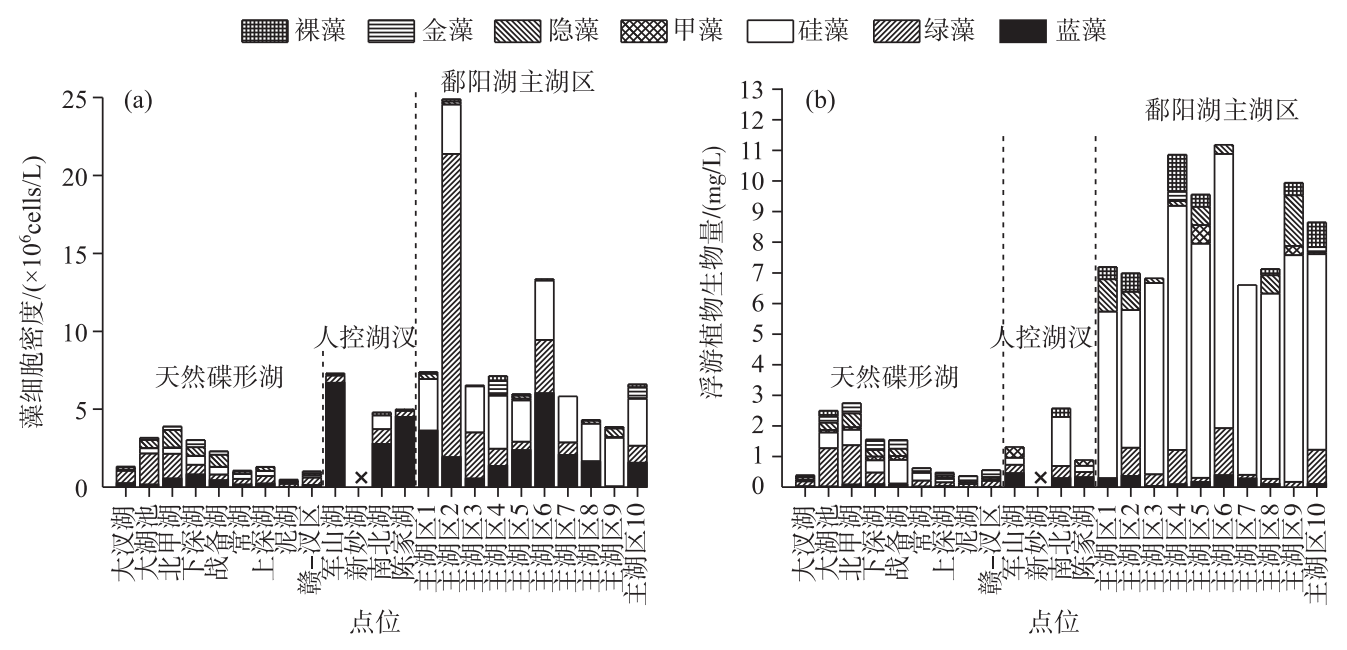

图 3 平水期鄱阳湖各湖区藻类细胞密度 (a) 与生物量 $(\mathrm{b})$ 组成

Fig.3 Density (a) and biomass (b) of algae in different areas of Poyang Lake during common water period

表 1 平水期鄱阳湖水体水环境参数间的 Pearson 相关系数

Tab.1 Pearson correlations between environmental factors in Poyang Lake during common water period

\begin{tabular}{|c|c|c|c|c|c|c|c|c|c|c|c|c|}
\hline & 叶绿素 a & 总氮 & 总磷 & 温度 & 透明度 & COD & $\mathrm{pH}$ & 溶解氧 & 水深 & 浊度 & 电导率 钑 & 铵态氮 \\
\hline 叶绿素 a & 1 & & & & & & & & & & & \\
\hline 总氮 & 0.430 & 1 & & & & & & & & & & \\
\hline 总磷 & -0.003 & $0.615^{* *}$ & 1 & & & & & & & & & \\
\hline 温度 & 0.445 & $-0.814^{* *}$ & -0.601 ** & * 1 & & & & & & & & \\
\hline 透明度 & 0.368 & -0.331 & -0.414 & 0.374 & 1 & & & & & & & \\
\hline COD & 0.454 & 0.137 & 0.258 & -0.080 & 0.119 & 1 & & & & & & \\
\hline $\mathrm{pH}$ & $0.522 *$ & $-0.772^{* *}$ & -0.414 & $0.930^{\text {** }}$ & * 0.318 & 0.067 & 1 & & & & & \\
\hline 溶解氧 & -0.430 & $0.783^{* *}$ & $0.569^{*}$ & -0.961 *** & $*-0.357$ & 0.004 & $-0.947^{* *}$ & $* \quad 1$ & & & & \\
\hline 水深 & $-0.565^{*}$ & 0.507 * & -0.053 & -0.495 & -0.032 & -0.235 & $-0.631^{* *}$ & $* \quad 0.440$ & 1 & & & \\
\hline 浊度 & -0.491 & 0.597 & $0.675^{*}$ & -0.529 & -0.775 ** & -0.416 & 0.276 & 0.236 & 0.526 & 1 & & \\
\hline 电导率 & -0.160 & $0.667^{* *}$ & $0.640^{\text {*** }}$ & $*-0.700^{* * *}$ & $*-0.067$ & 0.147 & $-0.657^{\text {*** }}$ & * $0.669^{\text {*** }}$ & 0.475 & 0.466 & 1 & \\
\hline 铵态氮 & -0.423 & $0.806^{* *}$ & 0.244 & $-0.725^{\text {*** }}$ & $*-0.110$ & 0.300 & $-0.760^{* *}$ & * $0.668^{* *}$ & $0.628^{* *}$ & 0.034 & 0.550 * & 1 \\
\hline
\end{tabular}

$* P<0.05 ; * * P<0.01$.

\section{2 丰水期鄱阳湖各水域水体营养盐、藻类及蓝藻毒素状况}

丰水期鄱阳湖碟形湖与主湖区已经融为一体, 二者为边缘水体和湖心水体间的区别. 鄱阳湖碟形湖区 总磷变化范围为 $0.056 \sim 0.219 \mathrm{mg} / \mathrm{L}$, 平均值为 $0.099 \mathrm{mg} / \mathrm{L}$; 主湖区总磷变化范围总磷变化范围为 $0.030 \sim$ $0.158 \mathrm{mg} / \mathrm{L}$, 平均值为 $0.060 \mathrm{mg} / \mathrm{L}$; 人控湖汉总磷变化范围为 $0.065 \sim 0.131 \mathrm{mg} / \mathrm{L}$, 平均值为 $0.096 \mathrm{mg} / \mathrm{L}$ (图 $4 \mathrm{a})$. 丰水期天然碟形湖总氮变化范围为 $0.461 \sim 1.171 \mathrm{mg} / \mathrm{L}$, 平均值为 $0.930 \mathrm{mg} / \mathrm{L}$; 主湖区总氮变化范围为 $0.818 \sim 1.836 \mathrm{mg} / \mathrm{L}$, 平均值为 $1.150 \mathrm{mg} / \mathrm{L}$; 人控湖汉总氮变化范围为 $1.203 \sim 2.112 \mathrm{mg} / \mathrm{L}$, 平均值为 $1.725 \mathrm{mg} / \mathrm{L}$ 
(图 4b). 综合富营养化指数方面, 天然碟形湖变化范围为 40.2 48.0, 平均值为 44.0, 总体处于中营养状态; 主湖区综合富营养化指数变化范围为 $44.1 \sim 56.3$, 平均值为 48.2 , 总体处于中营养状态; 人控湖汉变化范围 为 $54.1 \sim 69.6$, 平均值为 64.0 , 总体处于中度富营养化状态 (图 4c).
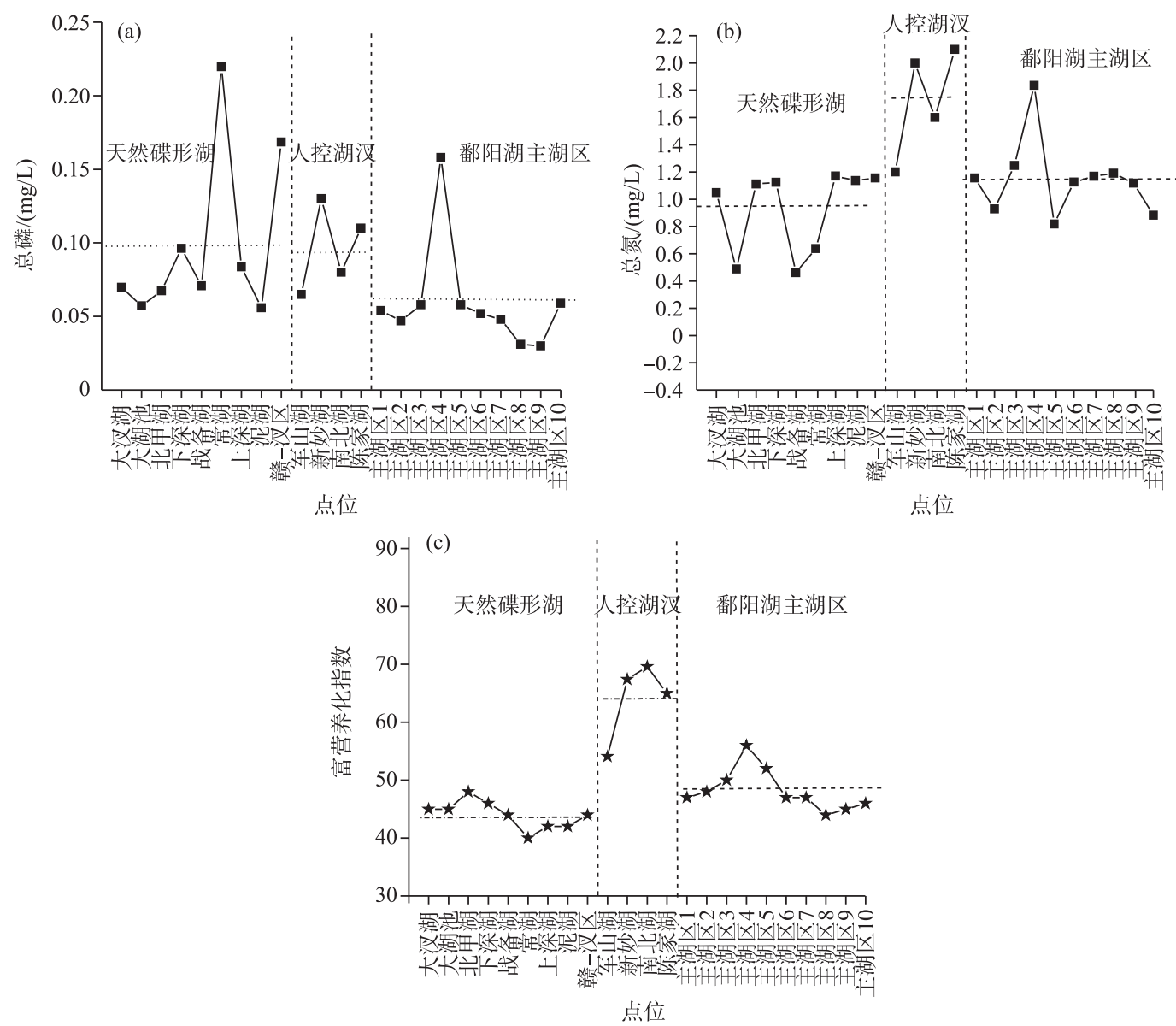

图 4 丰水期鄱阳湖各湖区总磷 (a)、总氮 (b) 和富营养化指数 (c) 分布 (水平虚线代表平均值)

Fig.4 Concentrations of total phosphorus (a), total nitrogen (b) and comprehensive nutrition state index (c) in different areas of Poyang Lake during flood period

鄱阳湖碟形湖丰水期藻类细胞密度变化范围为 $1.734 \times 10^{6} \sim 2.579 \times 10^{7}$ cells $/ \mathrm{L}$, 平均值为 $9.685 \times 10^{6}$ cells $/ \mathrm{L}$, 生物量变化范围为 $0.384 \sim 4.552 \mathrm{mg} / \mathrm{L}$, 平均值为 $2.509 \mathrm{mg} / \mathrm{L}$, 蓝藻和绿藻在数量和生物量上占据优 势地位; 主湖区藻细胞密度变化范围为 $2.525 \times 10^{7} \sim 6.159 \times 10^{7} \mathrm{cells} / \mathrm{L}$, 平均值为 $4.448 \times 10^{7} \mathrm{cells} / \mathrm{L}$, 生物量变 化范围为 $6.742 \sim 13.701 \mathrm{mg} / \mathrm{L}$, 平均值为 $10.799 \mathrm{mg} / \mathrm{L}$, 蓝藻在数量上占绝对优势地位, 其次为绿藻和硅藻, 生物量方面上述 3 种均占优; 人控湖汊藻细胞密度变化范围为 $2.669 \times 10^{7} \sim 1.182 \times 10^{8} \mathrm{cells} / \mathrm{L}$, 平均值为 $7.704 \times 10^{7}$ cells $/ \mathrm{L}$, 生物量变化范围为 $3.711 \sim 12.667 \mathrm{mg} / \mathrm{L}$, 平均值为 $7.624 \mathrm{mg} / \mathrm{L}$, 蓝藻在数量上为绝对优势 种, 生物量方面蓝藻、绿藻和硅藻等均为优势种 (图 5). 对丰水期藻类生物量 (叶绿素 a 浓度) 及多水质参数 进行 Pearson 相关分析, 结果表明, 丰水期藻类生物量与水体的总磷浓度呈正相关关系, 水体浊度也与水体 中的藻类数量呈现正相关 (即水中藻类越多, 水体浊度越高) (表 2). 丰水期对水柱中肉眼可辨蓝藻水华较为 明显区域进行了加密采样研究, 结果如图 6 所示, 丰水期鄱阳湖各区域微囊藻毒素浓度变化范围为 $0.23 \sim 0.48$ $\mu \mathrm{g} / \mathrm{L}$, 平均值为 $0.37 \mu \mathrm{g} / \mathrm{L}$, 所有水华点位毒素浓度均低于世界卫生组织推荐的饮用水安全标准 $(1 \mu \mathrm{g} / \mathrm{L})$, 总 体处于安全水平以内. 对蓝澡毒素与其他多因子 (含底泥 56 种主要金属元素及氮磷营养物等) 进行关联分 
析后, 发现该季节鄱阳湖水体蓝藻毒素浓度与该湖区底泥铁含量呈现较好的联合分布关系 (图 6a), 底泥铁 含量高的地方,其水体蓝藻毒素常比较高, 二者的线性相关系数见图 $6 \mathrm{~b}$.

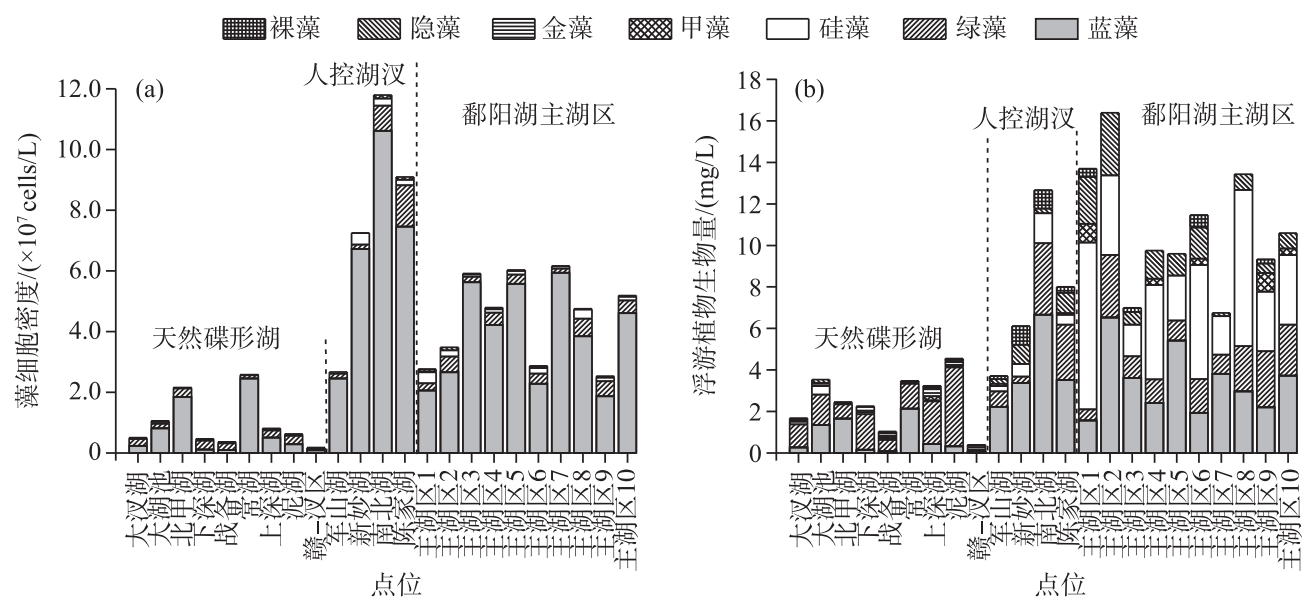

图 5 丰水期鄱阳湖各湖区藻类细胞密度 (a) 与生物量 $(\mathrm{b})$ 组成

Fig.5 Density (a) and biomass (b) of algae in different areas of Poyang Lake during flood period

表 2 丰水期鄱阳湖水体水环境参数间的 Pearson 相关系数

Tab.2 Pearson correlations between environmental factors in Poyang Lake during flood period

\begin{tabular}{|c|c|c|c|c|c|c|c|c|c|c|c|c|}
\hline & 叶绿素 a & 总氮 & 总磷 & 温度 & 透明度 & COD & $\mathrm{pH}$ & 溶解氧 & 水深 & 浊度 & 电导率 & 铵态氮 \\
\hline 叶绿素 a & 1 & & & & & & & & & & & \\
\hline 总氮 & 0.351 & 1 & & & & & & & & & & \\
\hline 总磷 & $0.543^{* *}$ & * 0.157 & 1 & & & & & & & & & \\
\hline 温度 & 0.258 & 0.023 & 0.313 & 1 & & & & & & & & \\
\hline 透明度 & 0.121 & $0.456^{*}$ & -0.005 & -0.190 & 1 & & & & & & & \\
\hline COD & 0.315 & 0.284 & 0.179 & 0.332 & -0.140 & 1 & & & & & & \\
\hline $\mathrm{pH}$ & -0.142 & -0.121 & $0.389^{*}$ & -0.028 & -0.229 & -0.062 & 1 & & & & & \\
\hline 溶解氧 & 0.622 & 0.040 & 0.484 & $0.826^{\text {** }}$ & $* * *-0.353$ & 0.033 & 0.287 & 1 & & & & \\
\hline 水深 & -0.094 & 0.278 & -0.321 & $-0.392^{*}$ & * $0.473^{* * *}$ & -0.093 & $-0.479^{*}$ & $*-0.780 *$ & 1 & & & \\
\hline 浊度 & $0.827^{* *}$ & * 0.535 & $0.716^{*}$ & 0.191 & -0.446 & 0.288 & 0.339 & 0.328 & -0.536 & 1 & & \\
\hline 电导率 & -0.176 & 0.044 & -0.148 & -0.248 & 0.056 & -0.038 & -0.191 & -0.080 & -0.055 & -0.124 & 1 & \\
\hline 铵态氮 & -0.020 & 0.156 & 0.052 & 0.217 & -0.283 & $0.700^{\text {** }}$ & 0.269 & 0.043 & -0.294 & -0.107 & 0.058 & 1 \\
\hline
\end{tabular}

$* P<0.05 ; * * P<0.01$.

\section{3 枯水期鄱阳湖各水域水体营养盐、藻类及蓝藻毒素状况}

枯水期鄱阳湖区以高温少雨天气为主, 碟形湖与主湖区发生了完全的分离, 成为了独立的鄱阳湖子湖 区. 枯水期鄱阳湖碟形湖区总磷变化范围为 $0.025 \sim 0.062 \mathrm{mg} / \mathrm{L}$, 平均值为 $0.043 \mathrm{mg} / \mathrm{L}$; 主湖区总磷变化范围为 $0.031 \sim 0.336 \mathrm{mg} / \mathrm{L}$, 平均值为 $0.105 \mathrm{mg} / \mathrm{L}$; 人控湖汊总磷变化范围 $0.103 \sim 0.211 \mathrm{mg} / \mathrm{L}$, 平均值为 $0.133 \mathrm{mg} / \mathrm{L}$ (图 7a). 枯水期天然碟形湖总氮变化范围为 $0.201 \sim 1.502 \mathrm{mg} / \mathrm{L}$, 平均值为 $0.581 \mathrm{mg} / \mathrm{L}$; 主湖区总氮变化范 围 $0.242 \sim 2.484 \mathrm{mg} / \mathrm{L}$, 平均值为 $0.919 \mathrm{mg} / \mathrm{L}$; 人控湖汉总氮变化范围为 $0.302 \sim 1.051 \mathrm{mg} / \mathrm{L}$, 平均 值为 0.713 $\mathrm{mg} / \mathrm{L}($ 图 7b). 综合富营养化指数方面, 天然碟形湖变化范围为 $30.2 \sim 54.1$, 平均值为 45.3 , 总体处于中营养 状态; 主湖区综合富营养化指数变化范围为 $45.3 \sim 54.0$, 平均值为 48.9 , 总体处于中营养状态; 人控湖汉变化 范围为 40.3 64.8, 平均值为 54.1, 总体处于轻度富营养化状态 ( 图 7c).

鄱阳湖碟形湖枯水期藻类细胞密度变化范围为 $0.977 \times 10^{5} \sim 1.257 \times 10^{7}$ cells $/ \mathrm{L}$, 平均值为 $2.793 \times 10^{6}$ 

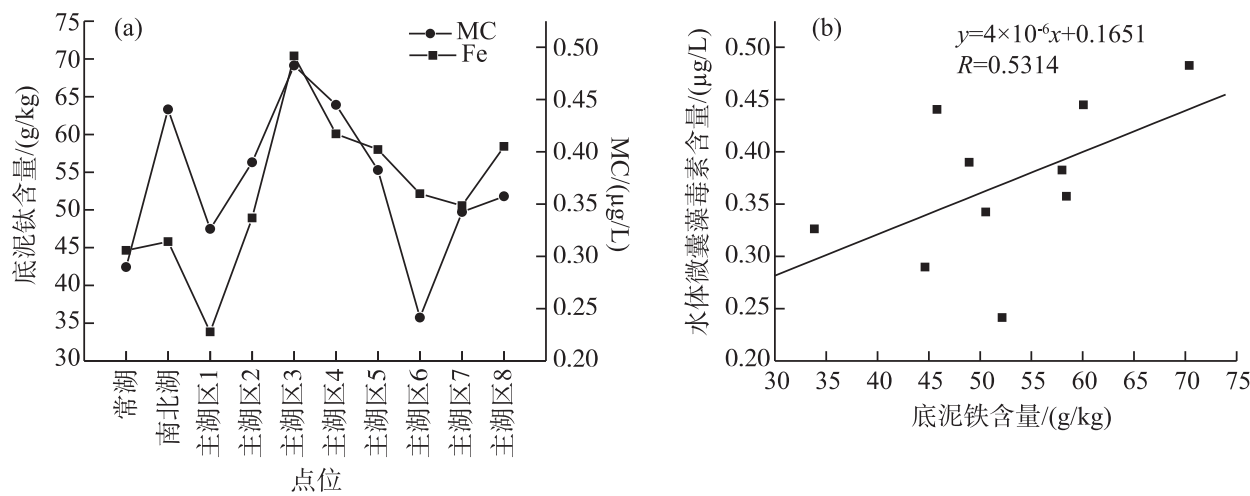

图 6 丰水期鄱阳湖底泥重金属含量与水体蓝藻毒素浓度 (a) 及其之间的相关性 (b)

Fig.6 Fe content of the sediment and MC concentration in the water of Poyang Lake (a) and their correlation (b) during flood period

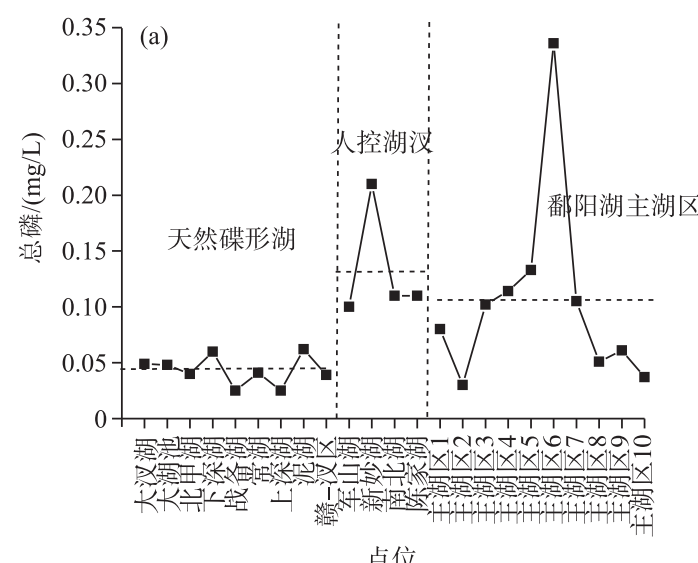

点位

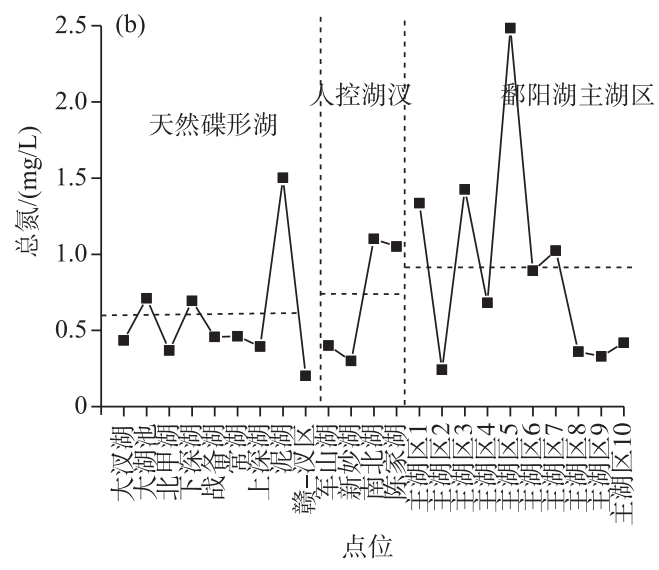

人控湖沌

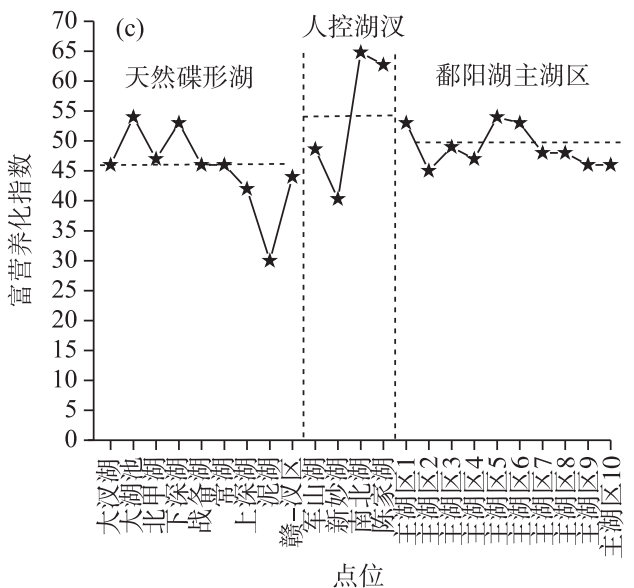

图 7 枯水期鄱阳湖各湖区总磷 ( a ) 、总氮 (b) 及富营养化指数 (c) 分布 (水平虚线代表平均值)

Fig.7 Concentrations of total phosphorus (a), total nitrogen (b) and comprehensive nutrition state index (c) in different areas of Poyang Lake during drought period 
cells/L, 生物量变化范围为 $0.023 \sim 5.349 \mathrm{mg} / \mathrm{L}$, 平均值为 $1.609 \mathrm{mg} / \mathrm{L}$, 蓝藻和绿藻在数量上占据优势地位, 硅 藻、蓝藻和绿藻在生物量上为主要优势种; 主湖区藻细胞密度变化范围为 $3.722 \times 10^{5} \sim 4.194 \times 10^{6}$ cells $/ \mathrm{L}$, 平 均值为 $2.099 \times 10^{6}$ cells $/ \mathrm{L}$, 生物量变化范围为 $0.251 \sim 3.927 \mathrm{mg} / \mathrm{L}$, 平均值为 $2.130 \mathrm{mg} / \mathrm{L}$, 硅藻、蓝藻和绿藻为 主要优势种; 人控湖汉藻细胞密度变化范围为 $6.689 \times 10^{6} \sim 1.131 \times 10^{8}$ cells $/ \mathrm{L}$, 平均值为 $5.423 \times 10^{7}$ cells $/ \mathrm{L}$, 生 物量变化范围为 $1.384 \sim 8.307 \mathrm{mg} / \mathrm{L}$, 平均值为 $5.907 \mathrm{mg} / \mathrm{L}$, 数量上蓝藻为绝对优势种, 生物量方面蓝藻、硅 藻和绿藻均占优 (图 8). 对枯水期藻类及多水质参数进行 Pearson 相关分析, 结果表明, 水体藻类生物量 ( 叶 绿素浓度) 与水体总氮、铵态氮浓度及电导率呈正相关关系 (表 3 ), 即水体中的铵态氮、总氮及无机类离子 化合物能够促进藻类的生长繁殖. 枯水期鄱阳湖水柱中肉眼可辨藻类较多区域微囊藻毒素浓度变化范围为 $0.10 \sim 0.22 \mu \mathrm{g} / \mathrm{L}$, 平均值为 $0.16 \mu \mathrm{g} / \mathrm{L}$, 所有水华点位毒素浓度均大幅低于世界卫生组织推荐的饮用水安全 标准 $(1 \mu \mathrm{g} / \mathrm{L})$. 尽管枯水期所选调查点位与丰水期点位差异较大,但所得结果与丰水期结论较为一致, 即鄱 阳湖水体蓝藻毒素浓度与该湖区底泥铁含量呈现一定的相关分布关系 (图 9a), 底泥铁含量高的地方, 其水 体蓝藻毒素常比较高, 二者的线性相关系数见图 9b. 在枯水期微囊藻毒素处于低浓度条件下, 毒素一铁之间 的相关性甚至高于丰水期毒素相对较高季节.

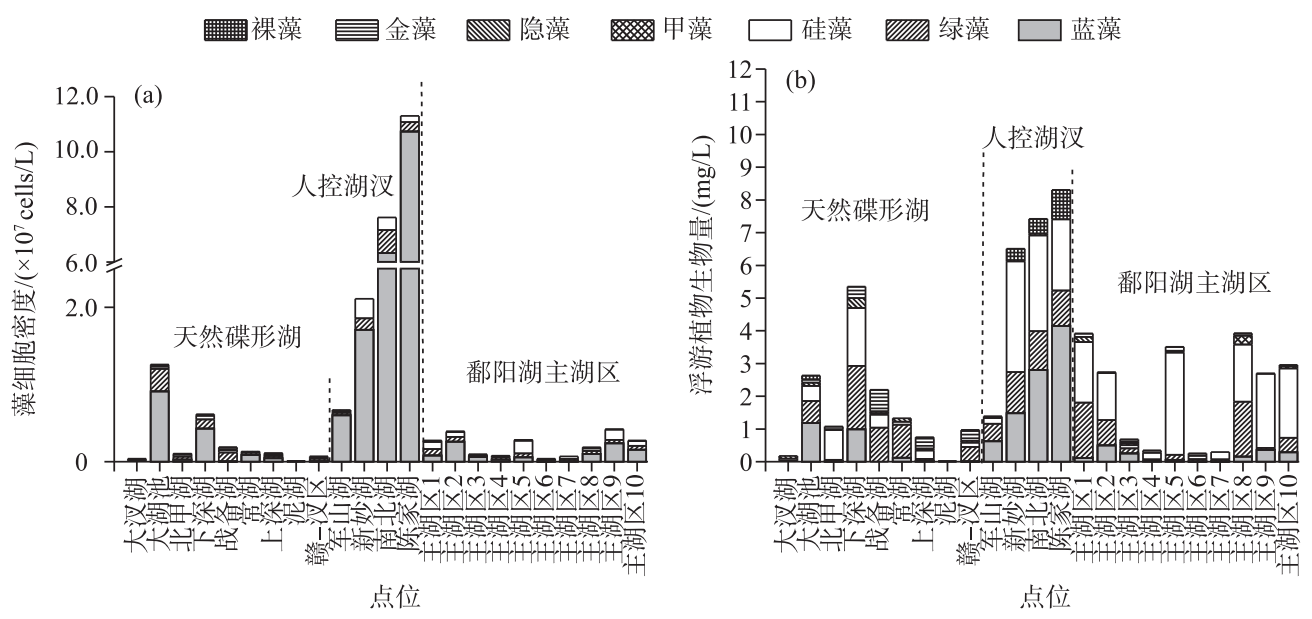

图 8 枯水期鄱阳湖各湖区藻类细胞密度 (a) 与生物量 $(\mathrm{b})$ 组成

Fig. 8 Density (a) and biomass (b) of algae in different areas of Poyang Lake during drought period

表 3 枯水期鄱阳湖水体水环境参数间的 Pearson 相关系数

Tab.3 Pearson correlations between environmental factors in Poyang Lake during drought period

\begin{tabular}{|c|c|c|c|c|c|c|c|c|c|c|c|}
\hline & 叶绿素 a & 总氮 & 总磷 & 温度 & 透明度 & COD & $\mathrm{pH}$ & 溶解氧 & 水深 & 浊度 & 电导率 铵态氮 \\
\hline 叶绿素 a & 1 & & & & & & & & & & \\
\hline 总氮 & $0.505^{*}$ & 1 & & & & & & & & & \\
\hline 总磷 & 0.123 & 0.246 & 1 & & & & & & & & \\
\hline 温度 & 0.027 & -0.056 & $-0.546^{*}$ & 1 & & & & & & & \\
\hline 透明度 & 0.249 & 0.358 & -0.225 & 0.058 & 1 & & & & & & \\
\hline COD & 0.002 & -0.026 & 0.372 & $-0.557^{*}$ & $*-0.111$ & 1 & & & & & \\
\hline $\mathrm{pH}$ & -0.279 & $-0.703^{* *}$ & -0.145 & 0.178 & -0.236 & -0.142 & 1 & & & & \\
\hline 溶解氧 & 0.106 & -0.049 & $0.550 *$ & -0.905 *: & $* * *-0.018$ & 0.579 ** & -0.101 & 1 & & & \\
\hline 水深 & -0.296 & -0.059 & 0.248 & 0.092 & -0.342 & -0.095 & $0.518^{*}$ & -0.217 & 1 & & \\
\hline 浊度 & 0.501 & 0.050 & 0.898 & 0.783 & -0.949 & 0.066 & 0.461 & -0.740 & 0.813 & 1 & \\
\hline 电导率 & $0.711^{* *}$ & $0.876^{* *}$ & 0.285 & 0.052 & 0.317 & -0.125 & $-0.502 *$ & -0.091 & 0.150 & 0.617 & 1 \\
\hline 铵态氮 & $0.508^{*}$ & $0.976^{* *}$ & 0.304 & -0.163 & 0.359 & 0.059 & $-0.740^{\text {*** }}$ & ** 0.073 & -0.244 & 0.052 & $0.849^{\text {*** }} \quad 1$ \\
\hline
\end{tabular}

$* P<0.05 ; * * P<0.01$. 

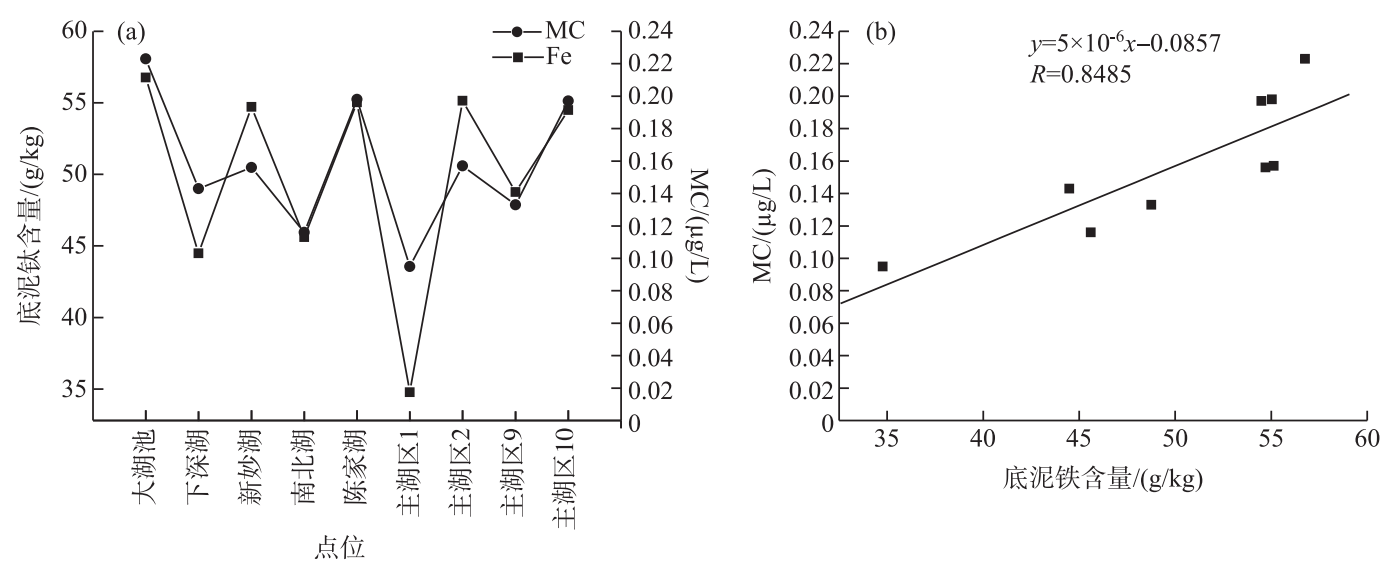

图 9 枯水期鄱阳湖底泥重金属含量与水体蓝藻毒素的含量 (a) 及其之间的相关性 (b)

Fig.9 Fe content of the sediment and MC concentration in the water of Poyang Lake (a) and their correlation (b) during drought period

\section{3 讨论}

\section{1 水位变动下鄱阳湖湖区生境变化对湖区藻类生长的影响}

平水季节鄱阳湖碟形湖区水生植物 (如灰化苔草) 大量生长, 周边莒草群丛占优势. 该季节碟形湖区藻 细胞总量及蓝藻的占比均大幅低于鄱阳湖主湖区和人控湖汉, 其原因可能与湖区大量水生植物生长对碟形 湖藻类生长的抑制作用有关. 研究表明, 鄱阳湖灰化苔草浸泡液对铜绿微囊藻的抑制作用较高, 枯灰化苔草 浸泡液对铜绿微囊藻的抑制率为 $81 \% \sim 88 \%^{[12]}$; 因此, 保护碟形湖区水生植物, 防止围旺开发破坏天然植 被, 对鄱阳湖水生态安全保障具有重要意义. 平水期藻类的生长与水深和水体 $\mathrm{pH}$ 相关, 水深的增加一方面 减弱了水体中下层的光照强度, 另一方面又稀释了水体营养盐的总浓度, 因此通常不利于藻类的生长. 湖泊 水库高水位运行是夏、秋季节对抗和消除蓝藻水华的常用手段之一 ${ }^{[20]}$. 每种藻类都有其适合的 $\mathrm{pH}$ 值范围, 而蓝藻偏好较高 $\mathrm{pH}$ 环境 ${ }^{[7]}$.

鄱阳湖人控湖汉多为水产养殖水域, 在水产养殖中对养殖环境的主要污染源是残饲和饲养动物的排泄 物, 其中影响最大的是磷. 现场调查发现鄱阳湖区水产养殖所用多为常规传统的配合饲料, 研究表明常规配 合饲料 (特别是以鱼粉为蛋白源的品种) 在实际投加应用中, 只有约 $20 \%$ 的磷会被鱼类有效利用, 剩余约 $80 \%$ 的磷将以粪便等排泄物的形式排人养殖水体, 对水环境的污染效应十分显著, 上述原因使得鄱阳湖人控 湖汉水域的平均总磷水平远高于其他湖区 ${ }^{[21-22]}$. 平水季节人控湖汉水域也存在一定生物量的水生植物, 与 同样受外来污染影响较大的鄱阳湖主湖区相比, 人控湖汉水体停留时间长, 因此植物和微生物等对氮的净 化较为充分, 这可能是该季节人控湖汉总氮水平低于鄱阳湖主湖区的原因之一 ${ }^{[23]}$. 平水期鄱阳湖主湖区藻 类平均细胞密度高于人控湖汉,但与人控湖汉不同的是蓝藻并非该季节鄱阳湖主湖区的绝对优势种,其可 能原因为: 该季节鄱阳湖水温在 $13 \sim 28^{\circ} \mathrm{C}$ 之间变动, 硅藻适温范围为 $10 \sim 25^{\circ} \mathrm{C}$, 该季节水温较适合硅藻生 $k^{[24]}$. 此外常温温度范围内一些单细胞藻类如绿藻生长速度也并不比蓝藻慢, 只有当水温为 $25 \sim 35^{\circ} \mathrm{C}$ 时, 蓝 藻的生长速度才会比其他藻类快, 较适合蓝藻生长, 因此主湖区硅藻、绿藻、蓝藻均占有一定优势度. 但在营 养盐组成方面二者差异较大, 人控湖汉处于高磷、低氮环境, 氮磷质量比 (N/P) 约为 6.3 , 磷供应丰富, 而主 湖区 N/P 比为 22.9 , 处于磷限制状态. 利比希最小定律 (Leibig law of the minimum) 表明磷才是控制大部分 湖泊藻类生长的主要因素 ${ }^{[5]}$. 研究表明 $\mathrm{N} / \mathrm{P}$ 比 $<7$ 时, 铜绿微囊藻的生长状态较 $\mathrm{N} / \mathrm{P}$ 比 $>7$ 时好, 说明其生长 主要受磷的限制, 充足的磷供应将促进微囊藻生长增殖进而形成水华, 人控湖汉的 N/P 比分布适合蓝藻( 如 微囊藻) 的大量繁殖 ${ }^{[25]}$. 除氮、磷元素外, 水体中各种无机盐如铁、锰和锌等同样为藻类生长所必需的营养 元素, 这些元素可以作为生化反应酶的辅助因子, 参与藻类化学反应, 促进藻类生长繁殖, 在一定条件下甚 
至是水华暴发的控制性因子, 这也是枯水期藻类生物链与水体电导率 (水中离子含量) 呈正向显著相关的原 因之一 ${ }^{[26-27]}$.

丰水期鄱阳湖各湖区水位升高, 大量平水期生长出来的植物被淹没在水下, 由于水体长时间浸泡及缺 光等原因部分植物开始死亡. 当植物死亡腐烂分解时, 其将向周边水体释放磷等营养物, 从而使部分碟形湖 水体营养盐较湖中心地区高 ${ }^{[28]}$. 但水体中部分植物浸泡液可对藻类生长起抑制作用, 碟形湖藻类特别是蓝 藻的数量与其他两种湖区相比仍然处于相对较低水平 ${ }^{[29-30]}$. 夏季丰水季节, 鄱阳湖各个湖区优势种主要为 蓝藻和绿藻, 其中主湖区和人控湖汊蓝藻已成为绝对优势种, 主要水华藻类种类有鱼腥藻 (特别是固氮鱼腥 藻)、微囊藻和浮丝藻等, 这与近年鄱阳湖其他研究所得的结论类似 ${ }^{[31]}$; 高叶绿素 a 浓度常出现在鄱阳湖高 水位和高水温期, 水位波动可加强鄱阳湖浮游植物 Chl. a 浓度的季节性变化 ${ }^{[32]}$. 丰水期鄱阳湖主湖区蓝藻 细胞密度较高的原因是多方面的, 一方面丰水季节降雨能促进蓝藻大量繁殖, 降雨使大量养分、有机质和微 量元素流人湖区, 从而促进蓝藻的快速繁殖 ${ }^{[3-35]}$. 另外, 在降雨季节, 水温、气温都很高, 而且变化速度快, 易 形成高温、静风和日照强、气压低的天气, 从而形成蓝藻暴发的条件 ${ }^{[36]}$. 炎热无风的晴天持续一段时间, 有 利于鄱阳湖局部流速较缓、相对静水的湖区形成水温垂直分层或水平分区, 蓝藻可选择在养分丰富、光照充 足、温盐度适宜的水层生活, 在种间竞争中占优势并大量繁殖 ${ }^{[37]}$. 如蓝藻中的微囊藻一般白天会上升到光 照最适表层, 夜晚下降到养分丰富的深层生活, 因而极易形成优势种群 ${ }^{[38]}$. 另一方面, 蓝藻具有自动悬浮调 节适应能力,夏季一般漂浮在水体表面并随水流方向迁移汇集 ${ }^{[39]}$. 主湖区点位一般都选在主航道和大湖湾 附近, 这些点位可以接纳来自 “五河” 各个水流漂浮过来的蓝藻, 特别是对于周溪大湾附近的点位, 来自贑江 信江和饶河区域的蓝藻均能汇集到这片水域,因而在这些点位常能看到一定长度的蓝藻水华聚集带. 目前 鄱阳湖主湖区原发性水华蓝藻数量与随水流而来的输人性蓝藻数量的比例组成依然不清楚, 尚需要深人研 究以确定主湖区水华蓝藻的确切来源, 从而为将来翻阳湖蓝藻水华的预防控制提供科学指导.

夏季丰水期藻细胞大量生长繁殖时, 在吸收水中太阳光进行光合作用的同时还通过反射散射等作用阻 碍阳光进入更深水层, 因此藻细胞越多, 水体的浊度也会越大. 磷是大部分湖泊藻类生长的关键元素, 水体 中磷负荷增加时, 藻类便会迅速大量繁殖, 富营养化的过程中首先是磷的增加. 磷元素除湖泊集水区的汇人 和底泥二次释放之外, 一般不能像固氮作用那样由微生物从空气中转化摄取, 因此许多湖库的富营养化治 理经验表明, 只要流域内严格控制有效磷浓度即可起到很好甚至关键性的藻类控制效果 ${ }^{[40]}$.

枯水期碟形湖与主湖区发生了完全的分离, 其水体流动性小, 各藻类种类数以小水流时最高, 生物量也 最高. 该季节也是人为开发利用浅水碟形湖最为繁忙的时节, 比如当地居民常在碟形湖边烧草肥地、“斩秋 湖” 和围湖圈养牲畜等, 上述行为极易在不利的水文天气条件下叠加短时间高浓度氮、磷等营养盐输人, 从 而引发蓝藻水华, 这也是近年枯水季鄱阳湖碟形湖常存在水华暴发的原因之一 ${ }^{[5]}$. 主湖区与天然碟形湖相 比, 其氮、磷营养盐浓度更高, 但该季节鄱阳湖已进人了完全的“河相”, 水体流速较快同时浊度极高, 不利于 藻类的生长繁殖, 因此该季节主湖区藻类优势种以硅藻和蓝藻为主. 全年碟形湖水质与藻类变化结果表明, 在丰水季水体与主湖区完全连通时, 其水体中的营养盐、藻类数量及毒素浓度均达到全年最高值; 而在不完 全连通季节, 上述数值均较低, 表明碟形湖自身的生态净化功能较好, 在自身生境不被彻底改变的条件下 (丰水期高水位改变了碟形湖的基本生境), 能较好地消化外源污染物, 维持自身生态平衡.

\section{2 鄱阳湖底质铁元素对湖区蓝藻毒素的影响}

丰、枯季节鄱阳湖水体蓝藻毒素浓度与该湖区底泥铁含量呈现规律性正相关关系 (平水季节鄱阳湖各 水域水体蓝藻毒素总体在方法检测限以下), 底泥铁含量高的点位其水体藻毒素浓度通常比较高. 金属元素 $\mathrm{Fe}$ 是藻类生长所必需的微量元素, 铁限制将严重抑制蓝藻的生长, 损害光合器官, 降低光合活性 ${ }^{[26]}$. 人为向 太湖东部区域输人 $\mathrm{Fe}$ 促进了太湖东区微囊藻细胞的生长增殖, 加剧了湖泊致癌蓝藻毒素总量增长风险 ${ }^{[27]}$. 鄱阳湖流域土壤以红壤为主, 红壤中主要粘粒矿物是高岭石、伊利石与铁氧化物, 当环境条件变化时红壤中 的铁元素可以释放出来供环境中其他生物体所用 ${ }^{[41]}$. 因此由于大量降雨或人为破坏流域内植被导致的水 土流失将可能为鄱阳湖输人大量铁元素, 从而加剧鄱阳湖区蓝藻水华有害毒素风险危害. 保护流域范围内 植被的完整性, 加强区域水土保持工作, 减缓鄱阳湖流域植被退化, 对鄱阳湖的水生态安全保障同样具有重 要意义. 
研究表明鄱阳湖底泥中铁元素对湖区蓝藻毒素可能具有相反的两种效应 ${ }^{[1]}$ : 一方面铁离子化合物在水 体透光区域对蓝藻毒素具有光化学降解作用. 铁类水合物如 $\mathrm{Fe}(\mathrm{OH})^{2+}$ 在光波长 $254 \mathrm{~nm}$ 处具有强吸收性, 其在紫外辐射下或其他有机物如柠檬酸诱导下就能进行光化学氧化反应, 从而快速氧化分解水体有机 物 $^{[42-44]}$; 另一方面, 过量铁的输人也可以抑制底泥微生物的活性, 从而引发蓝藻毒素的环境存量增长. 铁类 化合物可通过络合交联作用减弱微生物的活动能力, 降低其反应活性. 底泥中较高含量的金属化合物也可 降低底泥及水体中微生物对环境有机物的分解速率和自身固氮速率, 延缓生态系统养分循环, 损害微生物 物反应酶的合成并抑制微生物酶的活性等 (一般通过金属与酶类的结合使其失去催化活性) ${ }^{[45-46]}$. 研究表明 底泥中活性 $\mathrm{Fe}(\mathrm{III})$ 的添加量在 $75 \mathrm{mg} / \mathrm{kg}$ 以下时, $\mathrm{Fe}(\mathrm{III})$ 将促进底泥微生物对微囊藻毒素的降解; 活性 $\mathrm{Fe}$ (III) 的输人量超过 $75 \mathrm{mg} / \mathrm{kg}$ 时, $\mathrm{Fe}$ 的输人将降低微囊藻毒素的微生物降解速率 ${ }^{[1]}$. 上述结果表明在鄱阳湖 水体透光度较好的水域, 阳光可以照射到铁/重金属富集的底泥表层, 蓝藻毒素在铁促蓝藻细胞产毒作用、 铁一光催化降解毒素作用和过量铁抑制微生物降解毒素作用上的正负向作用间平衡, 综合表现为正负向环 境累积均有可能; 而在湖泊水体透光度较差的水域, 在铁促蓝藻细胞产毒作用和光催化降解蓝藻毒素作用 被无光或弱光条件抑制及微生物降解毒素被过量铁抑制的综合作用下, 蓝藻毒素的环境存量及持续时间可 能会得到加强, 其周边生物可能遭受更多的蓝藻毒素危害.

\section{4 结论}

1) 鄱阳湖存在多种不同水域,各水域的水质与藻类种群等差异大. 在各水文季节蓝藻均为人控湖汊藻 类优势种之一, 表明隔离开发湖汉对鄱阳湖水生态安全具有一定负面影响.

2) 在不同水文季节, 水深、水体 $\mathrm{pH}$ 、总磷浓度、总氮浓度和电导率等因子对鄱阳湖区藻类的生长可能起 到了关键控制作用.

3) 鄱阳湖水体微囊藻毒素浓度与底泥铁含量具有一定的正相关性, 铁对蓝藻生长和毒素的产生具有促 进作用.

\section{5 参考文献}

[ 1 ] Dai G, Peng N, Zhong J et al. Effect of metals on microcystin abundance and environmental fate. Environmental Pollution, 2017, 226: 154-162.

[ 2 ] Kong FX, Gao G. Hypothesis on cyanobacteria bloom-forming mechanism in large shallow eutrophic lakes. Acta Ecologica Sinica, 2005, 25(3) : 589-595 [ 孔繁翔, 高光. 大型浅水富营养化湖泊中蓝藻水华形成机理的思考. 生态学报, $2005,25(3): 589-595$.]

[ 3 ] Gan YQ, Guo YL. Evaluation analysis and remedy strategy for eutrophication in Wuhan Lake Donghu. Resources and Environment in the Yangtze Basin, 2004, 13(3): 277-281. [甘义群, 郭永龙. 武汉东湖富营养化现状分析及治理对策. 长江流域资源与环境, 2004, 13(3): 277-281.]

[ 4 ] Hu ZP. The habitat characteristics of White Cranes to live through the winter in Poyang Lake and the reaction for water level changing in the lake. Jiangxi Science, 2012, 30(1):30-35. [胡振鹏. 白鹤在鄱阳湖越冬生境特性及其对湖水位变 化的响应. 江西科学, $2012, \mathbf{3 0}(1)$ : 30-35.]

[ 5 ] Dai GF, Zhang M, Feng ML et al. Analysis of cyanobacteria bloom in Nanjishan Natural Reserve in Poyang Lake. Ecological Science, 2015, 34(4): 26-30. [戴国飞, 张萌, 冯明雷等. 鄱阳湖南矶湿地自然保护区蓝藻水华状况与成因分 析. 生态科学, $2015,34(4): 26-30$.]

[ 6 ] Zhao MX, Han BP. Analysis of factors affecting cyanobacteria bloom in a tropical reservoir ( Tangxi Reservoir, China). Acta Ecologica Sinica, 2005, 25(7): 1554-1561. [赵孟绪, 韩博平. 汤溪水库蓝藻水华发生的影响因子分析. 生态学 报, 2005, 25(7): 1554-1561.]

[ 7 ] Hu R, Xiong JX, Han BP. Structure and dynamics of phytoplankton assemblage in a small eutrophic reservoir with a short residence time. Ecology and Environmental Sciences, 2008, 17(4)：1319-1326. [胡韧, 熊江霞, 韩博平. 具有短水力 滞留的小型富营养化水库浮游植物群落结构与动态. 生态环境学报, 2008, 17(4): 1319-1326.]

[ 8 ] Reynolds CS, Irish AE. Modelling phytoplankton dynamics in lakes and reservoirs: the problem of in-situ growth rates. Hydrobiologia , 1997, 349(1/2/3) : 5-17. 
[ 9 ] Reynolds CS. Phytoplankton periodicity : the interactions of form, function and environmental variability. Freshwater Biology, 1984, 14(2) : 111-142.

[10] Mccausland MA, Thompson PA, Blackburn SI. The effect of changes in light availability caused by mixing on the growth of Anabaena circinalis (Nostocales, Cyanobacteria) and Aulacoseira sp. (Centrales, Bacillariophyceae). Phycologia, 2001, 40(6) : 530-541.

[11] Bulgakov NG, Levich AP. The nitrogen: phosphorus ratio as a factor regulating phytoplankton community structure. Archiv fur Hydrobiologie, 1999, 146(1) : 3-22.

[12] Li L, Chen F, Zhao RF. Allelopathic effect of soaking Carex cinerascens in Poyang Lake on Microcystis aeruginosa. Environmental Science \& Technology, 2016, 39(2): 1-5. [李林, 陈峰, 赵荣芳. 鄱阳湖灰化苔草浸泡液对铜绿微囊藻的 化感作用. 环境科学与技术, 2016, 39(2): 1-5.]

[13] Frena M, Quadros DPC, Castilho INB et al. A novel extraction-based procedure for the determination of trace elements in estuarine sediment samples by ICP-MS. Microchemical Journal, 2014, 117(21) : 1-6.

[14] Lei LM, Wu YS, Gan NQ et al. An ELISA-like timeresolved fluorescence immunoassay for microcystin detection. Clinica Chimica Acta, 2004, 348 (1/2) : 177-180.

[15] Xiong J, Yu FQ, Tian Q et al. The evolution of water quality and nutrient condition in Lake Dongting in recent 30 years. $J$ Lake Sci, 2016, 28(6) : 1217-1225. DOI: 10.18307/2016.0607. [熊剑, 喻方琴, 田琪等. 近 30 年来洞庭湖水质营 养状况演变特征分析. 湖泊科学, 2016, 28(6): 1217-1225.]

[16] Mao YT, Zhou XY, Wang ML. Study on the eutrophication status in Poyang Lake during lower water period. Journal of Nanchang University: Natural Science, 2014, 38(6) : 596-599. [毛玉婷, 周晓宇, 王毛兰. 枯水期鄱阳湖水体富营养 化状态评价. 南昌大学学报: 理科版, 2014, 38(6): 596-599.]

[17] Hu HJ, Wei YX eds. The Freshwater algae of China: Systematics, taxonomy and ecology. Beijing: Science Press, 2006: 1-1023. [胡鸿均, 魏印心. 中国淡水藻类——系统, 分类及生态. 北京: 科学出版社, 2006: 1-1023.]

[18] Hasle GR, Sournia A eds. Phytoplankton manual, monographs on oceanographic methodology. Paris: UNESCO, 1978.

[19] Mcnaughton SJ. Relationships among functional properties of Californian grassland. Nature, 1967, 216(5111): 168-169.

[20] Yang J, Lv H, Yang J et al. Decline in water level boosts cyanobacteria dominance in subtropical reservoirs. Science of the Total Environment, 2016, 557/558: 445-452.

[21] Ketola HG, Harland BF. Influence of phosphorus in rainbow trout diets on phosphorus discharges in effluent water. Transactions of the American Fisheries Society, 1993, 122(6) : 1120-1126.

[22] Holby O, Hall P. Chemical fluxes and mass balances in a marine cage farm. II. Phosphorus. Marine Ecology Progress, $1991,70(3):$ 263-272.

[23] Huang L. Nutrient removal ability and resistance of five hydrophytes under low-temperature conditions. International Journal of Environment \& Pollution, 2010, 42(4) : 388-398.

[24] Admiraal W. Influence of light and temperature on the growth rate of estuarine benthic diatoms in culture. Marine Biology, 1976, 39(1): 1-9.

[25] Yi WL, Wang GD, Liu XW et al. Effects of N/P ratios on the growth and some biochemical constituents of Microcystis aeruginosa. Journal of Northwest Sci-Tech University of Agriculture and Forestry, 2005, 33(6): 151-154. [易问利, 王国 栋, 刘选卫等. 氮磷比例对铜绿微囊藻生长及部分生化组成的影响. 西北农林科技大学学报, 2005, 33(6): 151-154.]

[26] Xing W, Huang WM, Liu GH et al. Effects of iron on physiological and biochemical characteristics of Microcystis wesenbergii (Kom.) Kom. (Cyanobacterium). Fresenius Environmental Bulletin, 2008, 17(12A) : 2034-2042.

[27] Xu H, Zhu G, Qin B et al. Growth response of Microcystis spp. to iron enrichment in different regions of Lake Taihu, China. Hydrobiologia, 2013, 700(1): 187-202.

[28] Du LG, Fang F, Guo JS et al. Characteristics of carbon, nitrogen and phosphorus release from dominant herbaceous plants in water-Level fluctuation zone of the Three Gorges Reservoir. Research of Environmental Sciences, 2014, 27(9) : 10241031. [杜立刚, 方芳, 郭劲松等. 三峡库区消落带草本植物碳氮磷释放及影响因素. 环境科学研究, 2014,27 (9) : 1024-1031.]

[29] Nakai S, Inoue Y, Hosomi M et al. Myriophyllum spicatum -released allelopathic polyphenols inhibiting growth of bluegreen algae Microcystis aeruginosa. Water Research, 2000, 34(11) : 3026-3032. 
[30] Körner S, Nicklisch A. Allelopathic growth inhibition of selected phytoplankton species by submerged macrophytes1. Journal of Phycology, 2002, 38(5): 862-871.

[31] Qian KM, Liu X, Qi LY et al. Variations of Anabaena in the transition levels between river-and lake-type of Lake Poyang. J Lake Sci, 2016, 28(3) : 566-574. DOI: 10.18307/2016.0312. [ 钱奎梅, 刘霞, 齐凌艳等. 鄱阳湖河湖转换期间鱼 腥藻 (Anabaena) 的变化. 湖泊科学, 2016, 28(3) : 566-574.]

[32] Liu X, Liu BG, Chen YW et al. Responses of nutrients and chlorophyll a to water level fluctuations in Poyang Lake. Environmental Science, 2016, 37(6) : 2141-2148. [刘霞, 刘宝贵, 陈宇炜等. 鄱阳湖浮游植物叶绿素 a 及营养盐浓度对 水位波动的响应. 环境科学, 2016, 37(6): 2141-2148.]

[33] Sanders JG, Riedel GF. Trace element transformation during the development of an estuarine algal bloom. Estuaries, 1993, 16(3): 521-532.

[34] Harris TD, Smith VH. Do persistent organic pollutants stimulate cyanobacterial blooms? Inland Waters, 2016, 6(2) : 124-130.

[35] Meng Q, Fu B, Tang X et al. Effects of land use on phosphorus loss in the hilly area of the Loess Plateau, China. Environmental Monitoring \& Assessment, 2008, 139(1/2/3): 195-204.

[36] Ren J, Jiang MS, Shang ZT et al. Study on the meteorological condition of blue-green algae fast growth in Lake Tai. Scientia Meteorologica Sinica, 2008, 28(2) : 221-226. [任健, 蒋名淑, 商兆堂等. 太湖蓝藻暴发的气象条件研究. 气象科 学, 2008, 28(2): 221-226.]

[37] Whitton BA, Potts M eds. The ecology of cyanobacteria: their diversity in time and space. Boston: Kluwer Academic, 2000.

[38] Lin J, Su YP, Zhong HZ et al. Vertical distribution of phytoplankton in a eutrophic reservoir, Shanzi Reservoir (Fujian) during summer stratification. $J$ Lake Sci, 2010, 22(2) : 244-250. DOI:10.18307/2010.0214. [林佳, 苏玉萍, 钟厚璋 等. 一座富营养化水库一福建山仔水库夏季热分层期间浮游植物垂向分布. 湖泊科学, 2010, 22(2) : 244-250.]

[39] Oliver RL. Floating and sinking in gas-vacuolate cyanobacteria 1. Journal of Phycology, 1994, 30(2) : 161-173.

[40] Miquel L, Frank VO. Controlling eutrophication by combined bloom precipitation and sediment phosphorus inactivation. Water Research, 2013, 47(17) : 6527-6537.

[41] Khan DH. Release of iron oxide in red-brown soil formation from the weathering of limestone. II.-Role of grass extract. Journal of the Science of Food \& Agriculture, 2010, 11(11): 632-635.

[42] Anipsitakis GP, Dionysiou DD. Transition metal/UV-based advanced oxidation technologies for water decontamination. Applied Catalysis B: Environmental, 2004, 54(3): 155-163.

[43] Wei S, Liu L, Li H et al. Photodecolourization of orange II with iron corrosion products and oxalic acid in aqueous solution. Applied Catalysis A: General, 2012, 417/418 (1) : 253-258.

[44] Chen R, Zhao S, Liu H et al. Preparation and photocatalytic activity of lepidocrocites obtained by photocatalytic oxidation of $\mathrm{Fe}$ (II) in the presence of citric acid. Journal of Photochemistry and Photobiology A: Chemistry, 2015, 312: 73-80.

[45] Lin C, Chen S, Cheng Y. Effect of metals on biodegradation kinetics for methyl tert-butyl ether. Biochemical Engineering Journal, 2006, 32(1) : 25-32.

[46] Nwuche CO, Ugoji EO. Effects of heavy metal pollution on the soil microbial activity. International Journal of Environmental Science \& Technology, 2008, 5(3) : 409-414. 